\title{
PENGARUH METODE IMPROVE TERHADAP KEMAMPUAN BERPIKIR KRITIS MATEMATIS MAHASISWA
}

\author{
M. Zaiyar ${ }^{1}$ \\ ${ }^{1}$ Institut Agama Islam Negeri Langsa, jalan Meurandeh, Langsa 24411, Indonesia \\ Email: m.zaiyar@iainlangsa.ac.id
}

\begin{abstract}
Abstrak
Kemampuan berfikir kritis merupakan salah satu kemampuan berpikir tingkat tinggi yang dibutuhkan mahasiswa untuk memahami konsep, menerapkan, mensintesis dan mengevaluasi informasi yang diperoleh sebagai proses penggunaan keterampilan berpikir secara aktif dan rasional sehingga setiap dalam mengambil keputusan dilakukan atas tindakan yang benar. Penelitian ini bertujuan untuk mengetahui pengaruh penggunaan metode improve terhadap kemampuan berpikir kritis matematis mahasiswa pada mata kuliah matematika diskrit. Metode yang digunakan dalam penelitian ini adalah quasi eksperimen dengan desain randomized pretest-posttest control group design. Instrumen yang digunakan berupa tes kemampuan berfikir kritis matematis berbentuk uraian dengan empat indikator. Analisis data menggunakan uji-t, dengan taraf sifnifikan $\alpha=0,05$ diperoleh $t_{\text {hitung }}=4,10$ dan $t_{\text {tabel }}=2,012$ sehingga $t_{\text {hitung }}>t_{\text {tabel }}$ maka Ha diterima dan Ho ditolak. Sehingga dapat disimpulkan bahwa terdapat pengaruh yang signifikan penggunaan metode improve terhadap kemampuan berpikir kritis matematis mahasiswa.
\end{abstract}

Kata Kunci: Metode Improve, Kemampuan Berpikir Kritis

\begin{abstract}
The ability to think critically is one of the higher-level thinking skills needed by students to understand concepts, apply, synthesize and evaluate information obtained as a process of using active and rational thinking skills so that every decision is made on the right course of action. This study aims to determine the effect of using the improve method on students' mathematical critical thinking skills in discrete mathematics courses. The method used in this study is a quasi-experimental design with randomized pretest-posttest control group design. The instrument used was a mathematical critical thinking ability test in the form of a description with four indicators. Data analysis using t-test, with a significant level $\alpha=0.05$ obtained tvalue $=4.10$ and ttable $=2.012$ so tvalue > ttable then $\mathrm{Ha}$ is accepted and Ho is rejected. So it can be concluded that there is a significant influence on the use of the improve method on students' mathematical critical thinking skills.
\end{abstract}

Keywords: Improve Method, Critical Thinking Ability

\section{PENDAHULUAN}

Banyak mahasiswa yang menilai bahwa matematika adalah pelajaran yang membutuhkan kemampuan analisis yang kuat, mampu bernalar terlebih di perguruan tinggi matematika dipelajari lebih spesifik sehingga matematika dirasa sulit dipahami dan tidak mudah dikuasai, disisi lain mahasiswa tidak memiliki minat yang tinggi bila menjumpai soal-soal matematika yang sulit dan bahkan cenderung untuk menghindarinya. Fakta ini merupakan alasan mendasar mengapa matematika dianggap sebagai pelajaran yang sulit. Faktor lainnya berasal doktrin yang dibangun sejak mereka menempuh pendidikan di sekolah menengah dan hal tersebut tersugesti dalam pikirannya sendiri atau 
bahkan mereka mensugesti pikirannya sendiri kalau matematika itu menyulitkan yang pada akhirnya mereka tidak berusaha untuk mengerjakan sendiri dan lebih memilih untuk mencontek temannya.

Kemampuan berpikir kritis matematis merupakan salah satu kemampuan yang dibutuhkan mahasiswa untuk memamhami konsep, menerapkan, mensintesis dan mengevaluasi informasi yang diperoleh. Kemampuan ini dibutuhkan untuk mengembangkan intelektual mahasiswa sebagai usaha menguji keyakinan atau pengetahuan berdasarkan bukti pendukungnya. Selain itu, berpikir kritis juga menuntut adanya kemampuan untuk mengenali, mengidentifikasi, dan memahami persoalan serta menemukan solusi atasnya. Mahasiswa yang memiliki tingkat kemampuan berpikir kritis yang baik mampu menyaring informasi, memilih layak atau tidaknya informasi sesuai kebutuhan, memeriksa kebenaran dari informasi dan menindaklanjuti informasi tersebut untuk dimanfaatkan dalam kehidupan mereka.

Berdasarkan hasil observasi aktivitas mengajar pada mata kuliah matematika diskrit didapati sebagian besar mahasiswa belum dapat menganalisis, mengidentifikasi, menghubungkan suatu masalah dalam menentukan solusi dari suatu masalah, hal ini juga disebabkan oleh kurangnya sikap mahasiswa terhadap matematika, mahasiswa tidak berperan aktif dalam pembelajaran karena mereka beranggapan bahwa dosen merupakan sumber pengetahuan utama yang ahli dibidangnya. Hal ini sejalan dengan hasil penelitian (Zaiyar \& Rusmar, 2020) melaporkan bahwa proses pembelajaran belum menitikberatkan pada mengembangkan kemampuan mahasiswa untuk berpikir kritis dan kreatif, mahasiswa tidak dibiasakan dengan menyelesaikan soal tingkat tinggi, bahkan hasil penelitian (Azizmalayeri et al., 2012) ditemukan sebagian besar lulusan sekolah dan universitas memiliki keterampilan yang buruk untuk mengidentifikasi dan menyelesaikan masalah yang rumit padahal sejalan dengan pendapat (Tan \& Halili, 2015) bahwa mahasiswa merupakan individu yang sudah pada tingkat perkembangan intelektual operasi formal tingkat tinggi, dan dituntut mampu mengkomunikasikan ide-ide matematika menjadi sebuah kreativitas, hal ini sejalan dengan penelitian (Marzuki et al., 2019) yang mengatakan bahwa aspek komunikasi dapat mengembangkan kemampuan berpikir tingkat tinggi seperti kemampuan berpikir kritis dan kreatif.

Rendahnya kemampuan berpikir kritis pada mahasiswa merupakan permasalahan serius yang tidak boleh diabaikan dalam pembelajaran matematika. Proses pembelajaran harus lebih menekankan pada penggunaan pendekatan pembelajaran yang berorientasi pada keterlibatan mahasiswa yang fokusnya pada pengembangan keahlian mereka yang bersifat adaptif, hal ini merupakan dampak dari perubahan paradigma sebagai hasil dari sebuah pembelajaran bagi mahasiswa (Jeremy Kilpatrick, Jane Swafford, 2001). Pembelajaran yang inovatif juga sangat diperlukan dalam membangun dan mengembangkan kualitas kemampuan berpikir mahasiswa (Hunter, 2009), hal ini sebagai wujud dari upaya memfasilitasi mahasiswa memiliki kemampuan berpikir kritis yang baik.

Menyahuti permasalahan tersebut di atas diperlukan pemilihan metode pembelajaran secara tepat yang dapat menumbuhkembangkan kemampuan berpikir kritis mahasiswa. Salah satu metode pembelajaran yang dapat diterapkan yaitu metode pembelajaran Improve. Metode pembelajaran 
Improve merupakan metode yang setiap kata dalam akronimnya merupakan langkah pembelajaran. Menurut Kramerski (Mujib, 2016) penjabaran dari akronim tersebut mempresentasikan semua tahap dalam metode Improve, yaitu: mengantarkan konsep baru, pertanyaan metakognitif, latihan, mereview dan mengurangi kesulitan, penguasaan materi, melakukan verifikasi, dan pengayaan sehingga dapat memperkaya pengetahuan mahasiswa. Penggunaan metode pembelajaran Improve lebih mengedepankan pengembangan keterampilan metakognitif dan kemampuan berpikir kritis. Hal ini tercermin dalam langkah pembelajaran metode pembelajaran Improve yaitu metacognitive questioning. Langkah dalam pembelajaran tersebut merupakan pengembangan proses berpikir melalui kesadaran akan apa yang dipahami sehingga secara tidak langsung akan berakibat pada kemampuan berpikir kritis mahasiswa.

Selain itu metode Improve merupakan suatu metode inovatif dalam pembelajaran matematika yang didesain untuk membantu mahasiswa dalam mengembangkan berbagai keterampilan matematika secara optimal serta meningkatkan aktivitas dalam belajar (Liberna, 2012) sehingga memperkaya pengetahuan mahasiswa dalam memecahkan masalah terutama masalah tingkat tinggi, karena kemampuan berpikir kritis sangat diperlukan agar terbiasa untuk berpikir secara beralasan dan reflektif, kemampuan ini dapat diasah dan dibiasakan oleh dosen dengan memberikan soal yang memacu mahasiswa untuk berpikir kritis, baik melalui soal konvergen maupun divergen.

\section{METODE PENELITIAN}

Jenis penelitian yang digunakan adalah eksperimen semu dengan desain penelitian berbentuk Randomized Pretest-Posttest Control Group Design (Sugiono, 2009), yaitu dengan menggunakan pembagian dua kelas untuk mengetahui perbedaan antara kelompok eksperimen dan kelompok kontrol. Kelas eksperimen dengan menggunakan metode improve dan kelas kontrol menggunakan model pembelajaran langsung. Penelitian ini dilakukan pada mahasiswa Prodi Pendidikan Matematika semester Ganjil 2019/2020. Teknik pengumpulan data menggunakan instrumen tes berdasarkan indikator kemampuan berpikir kritis matematis yang sudah divalidasi dan diujicoba sebelumnya. Data hasil tes kemampuan berpikir kritis dianalisis dengan menggunakan uji t dengan kriteria pengujian $\mathrm{H}_{0}$ diterima apabila $t_{\text {hitung }}<\mathrm{t}_{\text {tabel }}$ dan $\mathrm{H}_{0}$ ditolak apabila $\mathrm{t}_{\text {hitung }} \geq \mathrm{t}_{\text {tabel }}$.

\section{HASIL PENELITIAN DAN PEMBAHASAN}

Data yang diperoleh dalam penelitian ini adalah hasil tes kemampuan berpikir kritis mahasiswa pada mata kuliah matematika diskrit. Uji normalitas dalam penelitian ini menggunakan uji chi square. Adapun hasil uji normalitas pre test dan post test kemampuan berpikir kritis kelas eksperimen dan kelas kontrol sebagai berikut: 
Tabel 1. Uji Normalitas Tes Kemampuan Berpikir Kritis Matematis

\begin{tabular}{|l|c|c|c|c|}
\hline \multirow{2}{*}{ Kelas } & \multicolumn{2}{c|}{ Pre tets } & \multicolumn{2}{c|}{ Post test } \\
\cline { 2 - 5 } & $\chi_{\text {hitung }}^{2}$ & $\chi_{\text {tabel }}^{2}$ & $\chi_{\text {hitung }}^{2}$ & $\chi_{\text {tabel }}^{2}$ \\
\hline Eksperimen & 2,41 & 11,07 & 7,14 & 11,07 \\
\hline Kontrol & 10,10 & 11,07 & 6,44 & 11,07 \\
\hline
\end{tabular}

Dari tabel 1 di atas diketahui bahwa data tes kelas eksperimen dan kelas kontrol pada taraf signifikan $\alpha=0,05$ diperoleh $x^{2}$ hitung $<x_{\text {tabel }}^{2}$, sehingga dapat disimpulkan bahwa data hasil pre test dan post test baik kelas eksperimen maupun kelas kontrol berdistribusi normal. Adapun secara deskriptif dapat dilihat pada tabel berikut

Tabel 2. Deskripsi Data Pre-Test Kelas Kontrol dan Kelas Eksperimen

\begin{tabular}{|l|c|c|c|c|c|}
\hline \multicolumn{1}{|c|}{ Kelas } & N & Mean & Standar Deviation & Minimum & Maximum \\
\hline Eksperimen & 25 & 40,48 & 8,49 & 25 & 55 \\
\hline Kontrol & 25 & 40,02 & 7,99 & 20 & 50 \\
\hline
\end{tabular}

Dari data pada tabel 2 di atas terlihat bahwa nilai pre-test kelas kontrol sebanyak 25 mahasiswa memperoleh nilai minimum 20, nilai maksimum 50 dengan rata-rata 40,02 dan standar deviation 7,99. Sedangkan nilai pre-test kelas eksperimen memperoleh nilai minimum 25, nilai maksimum 55 dengan rata-rata 40,48 dan standar deviation 8,49. Jika ditinjau berdasarkan indikator kemampuan berpikir kritis matematis mahasiswa, persentase nilai pre test dapat dilihat pada tabel 3 berikut:

Tabel 3. Persentase Nilai Pre Test Berdasarkan Indikator Kemampuan Berfikir Kritis Matematis

\begin{tabular}{|l|c|c|c|c|}
\hline \multirow{2}{*}{ Kelas } & \multicolumn{4}{|c|}{ Indikator } \\
\cline { 2 - 5 } & $\begin{array}{c}\text { Memahami } \\
\text { Masalah }\end{array}$ & $\begin{array}{c}\text { Menemukan } \\
\text { Hubungan Logis }\end{array}$ & $\begin{array}{c}\text { Menemukan Cara Untuk } \\
\text { Penyelesaian Masalah }\end{array}$ & $\begin{array}{c}\text { Menganalisa } \\
\text { Data }\end{array}$ \\
\hline Eksperimen & $46 \%$ & $34 \%$ & $40 \%$ & $28 \%$ \\
\hline Kontrol & $51 \%$ & $24 \%$ & $36 \%$ & $27 \%$ \\
\hline
\end{tabular}

Berdasarkan tabel 3 di atas terlihat bahwa persentase nilai pre test pada indikator memahami masalah pada kelas eksperimen sebesar $46 \%$ atau sebanyak 12 mahasiswa, dan persentase nilai pre test pada kelas kontrol sebesar 51\% atau sebanyak 13 mahasiswa, sedangkan indikator menemukan hubungan yang logis antara masalah pada kelas eksperimen sebesar 34\% atau sebanyak 9 mahasiswa dan pada kelas kontrol sebesar 24\% atau sebanyak 6 mahasiswa, pada indikator menemukan cara untuk penyelesaian masalah pada kelas eksperimen sebesar $40 \%$ sebanyak 10 mahasiswa dan pada kelas kontrol 36\% sebanyak 9 mahasiswa sedangkan pada indikator menganalisis data pada kelas eksperimen sebesar $28 \%$ atau sebanyak 7 mahasiswa dan pada kelas kontrol sebesar $27 \%$ atau sebanyak 7 mahasiswa. 
Tabel 4. Deskripsi Data Post-Test Kelas Kontrol dan Kelas Eksperimen

\begin{tabular}{|l|c|c|c|c|c|}
\hline \multicolumn{1}{|c|}{ Kelas } & N & Mean & Standar Deviation & Minimum & Maximum \\
\hline Eksperimen & 25 & 73,34 & 8,72 & 55 & 85 \\
\hline Kontrol & 25 & 64,16 & 8,20 & 45 & 75 \\
\hline
\end{tabular}

Tabel 4 di atas memperlihatkan bahwa nilai post-test kelas kontrol dengan jumlah 25 orang memperoleh nilai minimum 45, nilai maksimum 75 dengan rata-rata 64,16 dan standar deviasi 8,20. Sedangkan nilai Post-test kelas eksperimen memperoleh nilai minimum 55, nilai maksimum 85 dengan rata-rata 73,34 dan standar deviation 8,72. Berdasarkan deskripsi data diatas menunjukan bahwa post-test kelas kontrol dan kelas eksperimen terdapat perbedaan dengan persentase ketuntasan $36 \%$ kelas kontrol dan $60 \%$ kelas eksperimen. Sedangkan persentase berdasarkan indikator kemampuan berfikir kritis matematis, hasil post test dapat dilihat pada tabel 5 berikut:

Tabel 5. Persentase Nilai Post Test Berdasarkan Indikator Kemampuan Berfikir Kritis Matematis

\begin{tabular}{|l|c|c|c|c|}
\hline \multirow{2}{*}{ Kelas } & \multicolumn{4}{|c|}{ Indikator } \\
\cline { 2 - 5 } & $\begin{array}{c}\text { Memahami } \\
\text { Masalah }\end{array}$ & $\begin{array}{c}\text { Menemukan } \\
\text { Hubungan Logis }\end{array}$ & $\begin{array}{c}\text { Menemukan Cara Untuk } \\
\text { Penyelesaian Masalah }\end{array}$ & $\begin{array}{c}\text { Menganalisa } \\
\text { Data }\end{array}$ \\
\hline Eksperimen & $85 \%$ & $46 \%$ & $77 \%$ & $69 \%$ \\
\hline Kontrol & $73 \%$ & $42 \%$ & $68 \%$ & $63 \%$ \\
\hline
\end{tabular}

Berdasarkan tabel 5 di atas terlihat bahwa mahasiswa dapat menjawab pada indikator memahami masalah pada kelas eksperimen sebesar 85\% sebanyak 21 mahasiswa dan pada kelas kontrol 73\% sebanyak 18 mahasiswa, sedangkan indikator menemukan hubungan yang logis antara masalah-masalah pada kelas eksperimen sebesar 46\% sebanyak 12 mahasiswa dan pada kelas kontrol 42\% sebanyak 11 mahasiswa, pada indikator menemukan cara yang dapat dipakai untuk menyelesaikan masalah pada kelas eksperimen sebesar 77\% sebanyak 19 mahasiswa dan pada kelas kontrol 68\% sebanyak 17 mahasiswa dan indikator menganalisis data pada kelas eksperimen sebesar 69\% sebanyak 17 mahasiswa dan pada kelas kontrol sebesar 63\% sebanyak 16 mahasiswa.

Untuk mengetahui ada tidaknya pengaruh metode improve terhadap kemampuan berfikir kritis matematis mahasiswa pada mata kuliah matematika diskrit, maka dilakukan uji hipotesis dengan menggunakan rumus uji t. Hasil perhitungan pengujian hipotesis disajikan pada tabel berikut:

Tabel 6. Rekapitulasi Hasil Perhitungan Uji Hipotesis Kemampuan Berpikir Kritis Mahasiswa

\begin{tabular}{|l|c|c|}
\hline \multicolumn{1}{|c|}{ Keterangan } & Kelas Eksperimen & Kelas Kontrol \\
\hline Sampel & & 64,16 \\
\hline Rata-rata & 73,34 & 67,30 \\
\hline $\mathrm{S}^{2}$ & 76,11 & \multicolumn{2}{|c|}{8,46} \\
\hline $\mathrm{S}_{\mathrm{gab}}$ & \multicolumn{2}{|c|}{4,10} \\
\hline $\mathrm{t}_{\text {hitung }}$ & \multicolumn{2}{|c|}{2,014} \\
\hline $\mathrm{t}_{\text {tabel }}$ & $\mathrm{H}_{0}$ ditolak dan $\mathrm{H}_{\mathrm{a}}$ diterima \\
\hline Kesimpulan
\end{tabular}


Hasil pengujian hipotesis kemampuan berpikir kritis mahasiswa dengan taraf signifikan $\alpha=$ 0,05 diperoleh $t_{\text {hitung }}=4,10$ dan $t_{\text {tabel }}=2,014$ dan ini berarti bahwa $t_{\text {hitung }}>t_{\text {tabel }}$, sehingga dapat disimpulkan bahwa $\mathrm{H}_{0}$ ditolak dan $\mathrm{H}_{\mathrm{a}}$ diterima, yaitu terdapat pengaruh yang signifikan pengaruh penerapan metode improve terhadap kemampuan berfikir kritis matematis mahasiswa prodi pendidikan matematika IAIN Langsa.

\section{KESIMPULAN}

Berdasarkan hasil analisis data menunjukkan bahwa pembelajaran dengan metode improve berpengaruh signifikan terhadap kemampuan berfikir kritis matematis mahasiswa. Hal ini dilihat dari nilai rata-rata post test kelas eksperimen dengan perolehan jawaban ditinjau dari indikator memahami masalah pada kelas eksperimen yaitu 85\% (21 orang) dan kelas kontrol 73\% (18 orang) pada indikator pertama, untuk indikator kedua pada kelas eksperimen yaitu 46\% (12 orang) dan kelas kontrol 42\% (11 orang), untuk indikator ketiga pada kelas eksperimen yaitu 77\% (19 orang) dan kelas kontrol 68\% (17 orang), dan indikator ke empat pada kelas eksperimen yaitu 69\% (17 orang) dan kelas kontrol 63\% (16 orang). Hasil analisis data diperoleh $t_{\text {hitung }}>t_{\text {tabel }}$ dengan taraf signifikan $\alpha=$ 0,05 diperoleh $t_{\text {hitung }}=4,10$ dan $t_{\text {tabel }}=2,012$ maka $H_{a}$ diterima dan $H_{o}$ ditolak sehingga dapat disimpulkan bahwa terdapat pengaruh yang signifikan penerapan metode Improve terhadap kemampuan berfikir kritis matematis mahasiswa prodi Pendidikan Matematika IAIN Langsa pada mata kuliah matematika diskrit.

\section{DAFTAR PUSTAKA}

Azizmalayeri, K., Mirshahjafari, E., Sharif, M., Asgari, M., \& Omidi, M. (2012). The impact of guided inquiry methods of teaching on the critical thinking of high school students. 3(10), 42-48.

Hunter, D. A. (2009). A practical guide to critical thinking: deciding what to do and believe. Philosophy, 258. https://doi.org/10.1002/9781118839751

Jeremy Kilpatrick, Jane Swafford, B. F. (2001). Adding It Up: Helping Children Learn Mathematics Jeremy. Society, II(6), 790.

Liberna, H. (2012). Peningkatan Kemampuan Berpikir Kritis Matematis Siswa Melalui Penggunaan Metode Improve Pada Materi Sistem Persamaan Linear Dua Variabel. Formatif, 2(3), 234854. https://doi.org/10.30998/formatif.v2i3.101

Marzuki, Asih, E. C. M., \& Wahyudin. (2019). Creative thinking ability based on learning styles reviewed from mathematical communication skills. Journal of Physics: Conference Series, 1315(1), 0-7. https://doi.org/10.1088/1742-6596/1315/1/012066

Mujib, Z. (2016). Mengembangkan Kemampuan Berfikir Kritis Melalui Metode Pembelajaran Improve. Al-Jabar: Jurnal Pendidikan Matematika, 07(2), 167-180.

https://doi.org/https://doi.org/10.24042/ajpm.v7i2.31 
Sugiono. (2009). Metode Penelitian Pendidikan Pendekatan Kuantitatif, Kualitatif, dan R\&D. CV. Alfabeta.

Tan, S. Y., \& Halili, S. H. (2015). Effective Teaching of Higher-Order Thinking (HOT) in Education. The Online Journal of Distance Education and E-Learning, 3(2), 41-47.

Zaiyar, M., \& Rusmar, I. (2020). Students' Creative Thinking Skill in Solving Higher Order Thinking Skills ( HOTS ) Problems. Al-Jabar: Jurnal Pendidikan Matematika, 11(1), 111-120. 